\title{
USE OF INFORMATION TECHNOLOGIES IN STUDYING PHRASEOLOGY IN THE COURSE OF UKRAINIAN AS A FOREIGN LANGUAGE
}

\author{
Larysa Azarova, Tetiana Pustovit, Liudmyla Radomska, Lyudmyla Horchinska \\ Vinnytsia National Technical University, Ukraine \\ ludarad9@gmail.com
}

Teaching Ukrainian as a foreign language requires a competent combination of traditional forms of learning and the possibilities of IT technologies. This study has been conducted to evaluate the effectiveness of IT technologies introduction in the educational process during the study of Ukrainian phraseology by foreign students. Authors conducted an experiment, which involved the introduction of IT technologies in the process of gradual study of phraseology at the lessons of Ukrainian as a foreign language during the academic year. 20 foreign students of the 3rd year participated in the experiment, from whom an experimental and control group of 10 students each was formed. Pre- and post-experimental tests to compare academic achievements, pre- and postexperimental surveys, informal interviews, observations of participants in the learning process were used as a means of data collection. The authors provided a system of tasks using Internet communications, computer presentations, online dictionaries, elements of the blended learning system for each stage of working with phraseological units. The obtained results confirmed the hypothesis: the use of IT technologies in the study of phraseologisms by foreign students increases their motivation for learning, and, as a consequence, improves learning performance. Indicators of academic achievement of the experimental group exceeded the starting level, while the control group noted a decrease in the indicators of academic achievement. Prospective directions for further research may be related to theoretical generalisations in the field of methodology of teaching Ukrainian as a foreign language, as well as to the development and implementation of modern complex methods using IT technologies.

Keywords: information technologies; Ukrainian as a foreign language; phraseologism; phraseology; experiment; educational process; Internet resource; blended learning.

\section{Introduction}

Today, Ukraine has outlined new priorities for the development and upgrading of the education system. The peculiarity of the current state of Ukrainian language teaching to foreign students is the modernisation of the methodical and methodological educational paradigm. The current process of language training for foreign students requires the introduction of the latest information technologies that enrich the content of the educational process. This will enable us to develop the ability of foreign students to adapt to the society and the community, to find and use new information; to systematise the acquired knowledge more effectively, to increase the motivation of learning and the level of language training.

In a relatively short period of time, linguistics has been enriched with new information technologies of education, which create greater opportunities for information perception, promote professional development, and provide teacher interaction with foreign students. Information technologies are a collection of techniques and means used to obtain, store, process and transmit information through computer systems.

In recent decades, the rapid development of information technologies has contributed to their use in linguistic research. Thus, in her work Azarova (2015) investigated the structural organisation of compound words in modern Ukrainian - the concept of a "golden" proportion, which establishes the harmony of their structural and phonetic construction using a linguistic-informational approach. Its essence is to combine traditional linguistic methods and techniques with methods borrowed from the theory of artificial intelligence, information theory, computerised processing of linguistic information, etc.

Information technologies for creating semantic structure in educational materials were considered by Barmak et al. (2019). The study has stated that IT for creating semantic structures of educational material is based on the use of appropriate information model, which allows acquiring knowledge and some skills in the study of any discipline (Barmak et al., 2019). In Rogushina's (2016) paper the specificities of Wiki-resources were analysed, ways of application of personalised ontologies of problems solved by the user in intellectual Web-applications were offered, namely - for semantic search (Rogushina, 2016, p.188).

There are a number of papers that investigated the techniques for relevant word ranking and extraction (Ventura \& Silva, 2007), effectiveness of IT for the automatic definition of terms in semantic content (Krak, Barmak \& Mazurets, 2016, 2018), the method of generalising grammatical structures for text translation using a computer (Krak, Barmak \& Romanyshyn, 2014), the text system for alternative conversational

(C) Larysa Azarova, Tetiana Pustovit, Liudmyla Radomska, Lyudmyla Horchinska. 2020. Published by Igor Sikorsky Kyiv Polytechnic Institute. This is an Open Access article distributed under the terms of the licence CC BY 4.0 
communications (Krak et al., 2017). The results of these studies are presented in publications to the Scopus Scientometric Database.

Due to the development of electronic learning (e-learning) and mobile learning (m-learning) in the modern information space, the development of digital learning management systems (LMSs) became more active, containing tools for administration, communication, knowledge assessment, creation of training courses, software complexes of different directions. E-learning issues in higher education establishments have already been widely explored (Górska, 2016; Lisetskyi, 2015, etc.). So a new direction "blended learning" has been formed in didactics. The term "blended learning" implies the combination of distance and classroom instruction, in which the participants and organisers of the educational process cooperate both asynchronously and synchronously in time using, at the same time, educational technologies based on the principles of open education: large-scale participation, accessibility, openness, comfort and interactivity (Boelens, Voet \& Wever, 2018).

Lisetskyi (2015) described basic tendencies in implementation of blended learning system, which in different proportions combines the elements of traditional and distance learning. Simpson (2016) examined those factors which are identified as the reasons for teachers having effectively implemented the technological components into a blended curriculum. Luzik, Akmaldinova and Tereminko (2019) studied the formation of the software engineering students' readiness for professional mobility in the educational and information environment of a technical university.

The criteria, the essential characteristics of this form of education have been defined in different ways: a flexible optimal combination of traditional classroom training with various new forms of e-learning, which involves the widespread use of modern information and communication technologies, enhancing the role of self-learning and responsibility for the result of educational activities in the presence of a large degree of educational freedom trajectories (Gahina \& Borysenko, 2018); a combination of forms and methods of organising formal, non-formal, informal learning and self-study that is accomplished to achieve predefined learning goals while maintaining a mechanism for controlling time, place, trajectories and pace of study, part of which is implemented remotely through information and communication technologies and technical learning tools (Buhaichuk, 2016); a combination of distance and traditional communication in integrated learning (Moebs \& Weibelzahl, 2006); a combination of the benefits of classroom learning (social interaction in which students need to manage the learning process) and e-learning characterised by flexibility and efficiency (Akkoyunlu \& Soylu, 2006); the integration of two learning models: traditional and electronic, where computer technologies are preferred (Graham, 2005). At the same time, we are convinced that the benefits of using a blended approach may help to offset a consistent lack of funding for training needs experienced by publicly-funded agencies. Other researchers have written about it too (Arbaugh et al., 2010; Lothridge, 2013).

Today, in linguodidactics, there is no systematic approach to solving many of the problems of teaching Ukrainian as a foreign language using IT technologies. On the other hand, getting acquainted with phraseologisms is an important step in learning a new vocabulary and memorising it as you learn a new language. Therefore, linguists emphasise the importance of the study of phraseology, give pieces of advice on the stage and method of introduction of phraseological material, and offer a number of tasks for the formation of linguistic competence. Recent studies in phraseology are related to the problems of the study of phraseological innovations in media discourse (Syzonov, 2018), the works on translation methods, equivalence and synonymy of phraseologisms, such as by Yashchuk (2014), are of primary importance. The use of information technology in the study of phraseology in a foreign language classroom is an open problem and therefore requires special in-depth study and presentation in a separate scientific work. This determines the relevance of the study.

The aim is to analyse the experience of implementing IT technologies in the process of step-by-step study of phraseology at the lessons of Ukrainian as a foreign language at Vinnytsia National Technical University (VNTU) during the academic year (2018-2019) and to offer an effective system of tasks using information and communication resources for studying, consolidating, reviewing, testing the knowledge and skills of foreign students.

The subject of our research, in comparison with other studies, is the identification of the possibilities of such information and communication resources as Internet communication, computer presentation, online dictionaries, electronic libraries, blended learning system to increase the effectiveness of studying phraseological units in the foreign language classroom.

The hypothesis is an assumption that the use of IT technologies in the study of phraseologisms by foreign students increases their motivation for learning, and, as a consequence, improves learning performance. 


\section{Methods}

For conducting a comprehensive study on the use of IT in the study of phraseology in the foreign language classroom we used a combination of quantitative (tests to compare academic achievements) and qualitative (oral interview before and after the experiment, informal interviews, observation of participants in the learning process) means of data collection.

In accordance with the stated aim, scientific comprehension and analysis of the problem have been carried out in synchronous terms. They have been implemented in four specific forms:

- a synchronous-descriptive research method related to observations and classification with a view to their further synthesis and generalisation and to determine the productivity of the use of a particular method;

- a descriptive method used to analyse the survey of all foreign students who participated in the experiment;

- a comparative method for highlighting the most effective information technologies;

- an experiment as a purposeful observation during the experimental testing of the step-by-step study of Ukrainian phraseology in a foreign language classroom using information technologies.

Participants: 20 foreign third-year students who studied in VNTU during 2018-2019 took part in the experiment. The experimental group (EG) consisted of 10 foreign students from the Faculty of Information Technology and Computer Engineering, the Faculty of Information Communications, Radio Electronics and Nanosystems, the Faculty of Power Engineering and Electromechanics and the Institute for Environmental Safety and Environmental Monitoring; accordingly, the control group (CG) consisted of 10 students who studied at the Faculty of Civil Engineering, Heat and Power Engineering and Gas Supply, Faculty of Mechanical Engineering and Transport, Faculty of Management and Information Security, Faculty of Computer Systems and Automation. Participants in the experiment included representatives of Latin American, African, Arab countries, and China at the age of 18-25 years of both sexes.

Instruments and Procedure. The tools and materials used during the experiment were PCs with software: Windows-8 and its related office applications, including PowerPoint-2010, as well as modern Internet resources, including cloud technologies in the Google-Forms application, as well as virtual libraries of different search engines.

Before the experiment, we used an initial test as well as a pre-experimental survey to check the level of students' language competence. The test contained tasks combined in four blocks for each of the language skills (speaking, writing, listening and reading), respectively, 25 points maximum per part, a total of 100 points per test. Each part contained language material in accordance with the curriculum with an emphasis on knowledge of the most commonly used Ukrainian phraseologisms and the ability to recognise them in speech.

The following questions were asked during the survey: 1) Do you understand the meaning of phraseologisms in the speech of Ukrainians easily? 2) Do you use phraseology in oral and written speech (how often?)? 3) What problems do you have when using phraseologisms? 4) What exercises were the most interesting to perform in the study of phraseologisms in Ukrainian language classes in previous courses and why? 5) What tasks were the most difficult and why?

We also conducted informal interviews with students to find out their personal attitudes to deepening their foreign language skills, to methods of learning language phraseologisms, to using phraseologisms in speech for effective communication between people of different languages, or whether there is a desire to improve Ukrainian language skills.

Based on the collected data, we concluded that the level of language training and the level of oral communication skills with the use of phraseological units and attitudes to the methods of studying phraseologisms were approximately the same in the two groups at the beginning of the experiment.

The experiment took place under the conditions of a real educational process. Its aim was to create such pedagogical conditions of studying that would effectively introduce the elements of blended learning, making maximum use of IT technologies to develop communication skills for students that means identifying and understanding the content of the most used phraseologisms in speech. Blended learning was implemented by combining student's work in the classroom supervised by the teacher and independent work to find and develop educational material. We created a system of tasks using information technologies for the gradual study of Ukrainian phraseology in a foreign language classroom. We have taken the following steps as a basis (Laguta, 2008, p. 139).

1) presentation of theoretical information about Ukrainian phraseology;

2) explanation of the new phraseological material;

3) performing different types of exercises in order to consolidate what has been learned;

4) revision of the material; 
5) performing certain types of work in order to test the knowledge and skills of foreign students.

The students of CG used only textbooks and hand-outs while working in the classroom. In EG in each stage, we used PowerPoint presentations, online dictionaries and online communication to achieve our primary goal of developing oral communication skills in Ukrainian using the most common phrase units (Appendix, Table 1).

PowerPoint presentation. The authors began to use presentations in the first stages of mastering phraseological units. Initially, students worked with an educational presentation composed by a teacher in which elements of lexical-grammatical tasks were presented in addition to visualisation. Subsequently, students were asked to create their own presentation under the supervision of the teacher (if necessary, it could be an individual, paired or group project), and finally - independently. Individual phraseologisms were the contents of the presentation; the composition of phraseologisms varied according to the needs and interest of different categories of students. The presentations were presented and discussed in a group, and then they selected those in which the phraseological unit is the most fully characterised in terms of content and possibilities of use.

Use of Internet resources. A wide variety of opportunities to work with Ukrainian phraseological units has been provided by the Internet: access to a wide range of references, information and country-research materials, and work with search engines, virtual libraries, etc. To overcome the difficulty in understanding and translating phraseologisms, students develop the ability to recognise them in the text. This helped to develop the skills of allocation in the text of the units, which, at first glance, are logical, contrary to the content, let us compare: The situation was catastrophic, it made the driver feel creepy all over (Ukr. aж мурашки забігали по спині) and The over-ground cone in the forest ants may reach two meters of height, they run high. Sophia turned round to find the phone, but it was nowhere-it disappeared into the air (Ukr. як корова язиком злизала)! and The cows were grazing in the spacious yard, delightfully licking off the morning dew.

Students searched for metaphorical elements in such sentences, words used in both literal and figurative meanings, and they compared content.

International students took full advantage of networking opportunities while making PowerPoint presentations. The following tasks were also proposed:

1. You have heard a new saying to roll in money (Ukr. хоч греблю гати). Find on the site and clear up its meaning. Does your native language have phrases of similar meaning? In what situations can it be used?

2. Get phraseologisms on the topic (or the proposed communication situation) using the online resources.

The teacher indicated the sites that could be used: https://svitslova.com/idioms-dictionary.html; https://supermif.com/frazeologizm/eng/ phraseology-dictionary.html; http://lcorp.ulif.org.ua/dictua/; http://slovopedia.org.ua/49/53392-0.html; http://rozum.org.ua. Students with a relatively high level of language proficiency searched independently and were given the task to analyse several sites and identify the most suitable for foreigners studying Ukrainian. Also, tasks for revision of the studied material were offered, the exercises of various complexity were relevant:

1. Use the online dictionaries to find out the meaning of phraseology units / get as many phraseologisms as possible to a particular word, and make a sentence with them.

2. Explain the origin of certain set expressions using, for example, Wiktionary's "List of Phraseologisms of the Ukrainian Language", which provides a list of phraseologisms with meanings and their sources of origin. https://uk.wiktionary.org/wiki/ Application: List of Phraseologisms of the Ukrainian Language.

3. Use the Internet to get Ukrainian correspondences to native language phraseologisms, put them into context (this task is easy to do by the algorithm: native language phraseologism $\rightarrow$ its meaning in native language $\rightarrow$ Ukrainian translation of phraseologism $\rightarrow$ phraseologism-correspondent in Ukrainian; you can find the answer using searches, for example, the request of phraseologism нічого не робити "do nothing" gives the result "stare at the wall, idle, act the fool, fool around, be bedridden", etc. (Ukr. бити байдики, бомки бити, ханьки м'яти, собак ганяти, дурня валяти (клеїти), тав ловити; горобиям дулі давати; лежати лежнем, еtс.).

4. Add phraseological synonyms / antonyms to specific words or phraseologisms using, for example, online dictionaries at http://rozum.org.ua/, https://archive.org/ details / frazeol_antonimi, etc.

5. Draw a linguistic analogy and find out if there is phraseologism in your own language that is translated into Ukrainian literally.

6. Make a videoconference with your friends in Ukrainian using learned phraseologisms in your communication, etc. 
The students sent the result of their work to the teacher using any convenient means of electronic communication. At the stage of testing knowledge of the phraseologisms teachers and students worked in online testing, self-assessment and online surveys, created using the free tool "Google-forms". It is offered by the Google Drive app with the Google Form feature, created to form different blocks of questions. It is convenient to create, edit and fill forms on any device at any time. The algorithm for working with Google forms has been defined: 1) in the Google Drive application in the menu "Create" select "Form" and give access to the desired users; 2) indicate the name of the document; 3) in the blank form create a question by specifying its name, explanation, type and choose if it is obvious; 4) click "Submit Form" and "Finish". According to our observations, the following tasks for the analysed online testing proved to be the most successful:

1. Determine in what context the phraseologism is correctly used.

2. Which of the following explanation reflects the phraseologism ...?

3. Put the phraseologism into one of the sentences without changing its content.

4. What is the meaning of this phraseologism? (for open answer)

5. Which of the following phraseologisms do you think are synonymous / anonymous to the meaning to the phraseologism ...?

6. Choose the correct meaning of phraseologism ... etc.

The test results were automatically sent to the teachers via e-mail, which enabled them to respond to mistakes quickly, adjust their work with students, enhancing and consolidating knowledge of relevant material. Group work, conversation, discussion, and error correction online were noted as productive methods of processing test results.

Foreign students performed separate tasks in phraseology in JetIQ, the information and educational environment of VNTU. JetIQ is an electronic support system of learning process that is the only integrated client-server educational system that implements the functions of distance and blended learning and higher education institution management. The electronic system contains modules for support of scientific research and methodological work, connection with scientific and methodical repositories, possibility of prompt questioning of students on the choice of disciplines, interaction with teachers and the dean, publication of news, use of corporate e-mail, connection with scientific metrics bases, creation of online tutorials, etc. The authors used the following features of the JetIQ system: presentation of educational material; creation of different forms of visual material for visualisation of lexical units; organisation of independent work of foreign students; providing individual work at different stages of studying; testing.

At the final stage of the experiment, we used diagnostic final testing and post-experimental survey of students. The obtained results of the experimental and control groups were compared and summarised. The final test structure was similar to the initial test offered to students at the beginning of the experiment, but each block contained two types of tasks: 1) tasks to assess the skills of identifying learned phraseologisms in context, understanding their meaning and application in their own speech; 2) tasks that involved the recognition of unfamiliar phraseologisms in oral and written text and the use of various means to clarify their meaning quickly.

The post-experimental survey was aimed at finding out how the situation changed after the experiment, so it included questions similar to the pre-experimental one: 1) Did the recognition and understanding of the meaning of phraseologisms in Ukrainian speech improve? 2) Do you use phraseology in oral and written speech more often? 3) What problems do you have when using phraseology now? 4) What exercises were the most interesting to perform in the study of phraseologisms in the Ukrainian language classes this year and why? 5) What were the most difficult tasks this year and why? These data were also compared with previous results.

Ethical issues. The participants gave their informed consent for participating in the study. They were informed of the withdrawing possibility, with no other consequences on their status.

\section{Results}

In the 2018-2019 academic year in Vinnytsia National Technical University, there was conducted an experimental testing of the use of IT technologies in the study of phraseology in the courses of Ukrainian as a foreign language to assess their effectiveness for the formation of foreign students' language competence. Participants' skills in recognising, understanding, and using phraseologisms were assessed before and after the experiment.

We calculated the statistics obtained in the initial test as a percentage and found that the number of students who completed the tasks of the four blocks of the initial test with scores above 15 was as follows: $71 \%$ in EG and $73 \%$ in CG, and the average score (according to 5 point evaluation system) was 3.8 (EG) and 
3.85 (CG). This showed that the vast majority of students, namely about $80 \%$ (79\% in EG and $78 \%$ in CG), have difficulty perceiving Ukrainian phraseologisms in oral and written speech, and $90 \%$ of students do not use them in speech. The pre-experimental survey showed that 90\% (EG) and 92\% (CG) of the surveyed students consider the task of studying phraseologisms difficult and mostly uninteresting.

Final testing showed that EG students had better results than CG students. The number of students who completed the tasks of the four parts of the final test with scores of more than 15 points in EG is $82 \%$ (at the beginning of the experiment - 71\%), and in CG - 70\% (at the beginning - 73\%). The average score in CG was 3.7 points, in EG - 4.2 points, which exceeds the initial level of knowledge by $12 \%$ in EG and shows a $7 \%$ decrease in the average score in CG.

Analysis of the oral survey of students in comparison with the results at the beginning of the experiment allowed us to evaluate objectively the results of the experiment and identify the position of students in relation to the proposed forms of work. Namely: $60 \%$ of students (at the beginning of the experiment $79 \%$ ), in CG and 80\% (78\%) in EG have difficulties in understanding Ukrainian phraseologisms in oral and written language; the task of studying phraseologisms is considered difficult and mostly uninteresting in EG by $26 \%$ of students (at the beginning of the experiment 90\%), in CG - 92\% (in the beginning 90\%); 54\% of students in EG and 5\% of students in CG use of phraseologisms in speech. In addition, $98 \%$ of surveyed students named the system of tasks using information and communication resources, which were used in the EC, as the most effective one for the study, consolidation, revision and testing of knowledge.

The obtained data allow us to state that the use of IT technologies, elements of blended learning as additional teaching aids in teaching Ukrainian as a foreign language has a positive effect on the formation of language competence of foreign students. Our experiment confirmed the hypothesis that the effectiveness of language competence and motivation to teach foreign students increases if IT technologies are used in the educational process.

\section{Discussion}

In the process of developing communication skills of foreign students with the use of the Ukrainian phraseology, the use of different types of IT technologies makes it possible, in the absence of a natural Ukrainian-speaking environment, to create conditions that are as close as possible to real language communication in Ukrainian. We have developed a system of tasks to foreign students at each stage to increase students' interest and, as a consequence, to increase the effectiveness of their study of Ukrainian phraseology. After all, understanding the phraseological units in direct spoken language is one of the most difficult tasks for a foreign student in studying the course "Ukrainian as a Foreign Language".

Taking into account the results of their research, the authors can argue that the use of IT technologies intensifies and significantly increases the efficiency of the process of learning to understand and use Ukrainian communicative phraseological units. These technologies improve the performance of both the classroom work and the independent work of foreign students with Ukrainian phraseologisms. The authors have proved in practice the hypothesis that the use of IT technologies contributes to the individualisation of the educational process, increasing the amount of work performed. It is very important that the use of multimedia in teaching Ukrainian as a foreign language allows the audience to create conditions that are as close as possible to real communication in a foreign language. This is noted by other researchers (Roman, 2015, p. 44).

The intensification of education in modern higher education institutions, the reduction in the number of classroom hours of language training for foreign students, encourage the search for such a model of language education that would allow the acquisition of a large amount of educational material in a short period of time. The principles of blended learning contribute to this as much as possible. As it turned out, blended learning intensifies the interest of foreign students in learning the Ukrainian language and, in particular, in facilitating the perception and memorisation of Ukrainian phraseologisms. The benefits of blended learning have been discussed in previous studies.

Obviously, a compulsory component of blended learning is e-learning with the use of modern information technologies. Such a component of studying Ukrainian as a foreign language can be realised through the creation of a separate e-course (for example, on the Moodle platform) or through the use of various sites, applications, programmes with support for online communication (Facebook, Viber, Google Form, e-mail, etc.). Ukraine has already had considerable experience in the creation of educational e-courses, in particular, the experience of specialists in the theory and practice of using the Moodle learning management system has been collected on the site http://2016.moodlemoot.in.ua/. Opportunities of information technologies can be used effectively at any stage of language acquisition: the study of the 
theoretical material, its consolidation, control of students' skills, generalisation and systematisation of the studied material.

It should be noted, however, that in Ukrainian universities, unfortunately, the blended learning system as a form of application of information technologies does not fully function as a separate kind of pedagogical process. Its implementation implies additional costs due to the need for full computer support, constant access to the Internet, and technical support. On the other hand, we agree that it is necessary to improve the content of existing programmes in the language disciplines by separating blocks for remote processing (Gahina \& Borysenko, 2018, p. 181). The results of our study were also confirmed by Lisetskyi's (2015) idea that the use of different forms of online learning in combination with traditional learning makes it possible to achieve higher educational efficiency, but the transition from traditional forms of learning to the area of free educational space is not easy and requires a lot of effort (p. 32). At the same time, this innovative technique is undoubtedly one of the most promising ones, because it provides the students with the need for adequate, up-to-date teaching that is relevant to the current information technology capabilities. Our results showed that the use of Internet communication, computer presentation, online dictionaries, electronic libraries, blended learning system quickly enriches the vocabulary of foreign students and improves their ability to easily perceive and produce the Ukrainian language in various situations of oral communication.

Taking into account the above, it is optimal to consider the use of blended learning elements at certain stages of language acquisition. And we consider our research a first step in applying the blended learning system to the study of Ukrainian as a foreign language.

It turned out that students' learning in the Ukrainian-language global networking environment with the support and guidance of a teacher significantly increases time and improves their contact with the language. Already at the first stages of studying the phraseological unit, the teacher can give a task to find out its meaning on the relevant site, to find images that represent the content of phraseologism and so on. We are convinced that the system of tasks on the topic "Ukrainian phraseology", which can be implemented with the help of information technologies, should be developed taking into account the specifics of phraseologisms, the peculiarities of their translation in the native language for foreign students. After all, phraseologisms often contain a metaphorical element, and in fact, of Ukrainian origin, also have a pronounced national colour, mostly phraseological units do not have absolute correspondences in the native language of foreigners. Therefore, the purpose of translating phraseologisms is to reproduce the full equivalent of the target language. There is a lot of information about the methodology of such phraseological translation in Yashchuk (2014), which summarises different ways of translating phraseological synonyms from English into Ukrainian.

Kudina and Kudin (2014) have already determined that language teaching requires the use of methodological systems containing elements of interactivity, individualisation of the student's learning trajectory, operational control of language acquisition in different modes of independent search and at different levels of complexity (Kudina \& Kudin, 2014, p. 17). Information technologies certainly meet these requirements. In particular, you can say the same about the formation of communication skills using phraseological units in PowerPoint presentations. As a means of visualisation and a kind of educational text, presentation is effective even for students with minimal linguistic reserve, because it allows them to see and remember new realities and linguistic phenomena.

VNTU has formed its own information and educational environment. It takes into account the needs and specifics of a particular institution: the information and learning environment contains a search server when the student's learning also actively continues outside the classroom; there is access to the information and educational environment of the university, city, country, etc. in the real way (portal of the university, the site of the department, etc.) or in a virtual way (participation in virtual conferences, discussion of problems in forums, search of information on the Internet, etc.). The educational material is focused on web technologies, email, search engines, chatting. The capabilities of the electronic support system of the JetIQ educational process, created at VNTU, markedly intensified the formation of the necessary complex of language and communication skills of different levels in the process of studying Ukrainian by foreign students. In addition to the opportunities used by the authors, the future plans include a virtual visit to museums while working with the material of a national subject; application of various forms of control of the level of formation of relevant competences; regular updating of educational materials, combination of traditional and distance learning, etc.

The authors do not offer a single scenario for working with Ukrainian phraseologisms in a foreign language classroom with the use of information technologies, as there are many options. One of the significant advantages of IT technologies is the ability to create an individual educational scenario for a 
specific group and for an individual student, based on a number of factors: professional orientation, stage of study, level of speech competence, level of motivation, etc.

\section{Conclusions}

The purpose of the research was to analyse the peculiarities of the use of modern IT technologies, which contribute to the efficient and gradual study of phraseology at the lessons of Ukrainian as a foreign language; providing various types of tasks for studying, consolidation, revision, and in order to test the knowledge and skills of foreign students.

The use of innovative educational technologies in the process of learning Ukrainian as a foreign language is essential and important, in particular when studying phraseology in a foreign language classroom. It increases the motivation of foreign students to learn a foreign language, makes the learning process more diverse, creative, interesting, and provides the acquisition of skills that facilitate full communication in the Ukrainian language and adaptation in a foreign language environment. It should be noted that the use of the above technologies creates for students-foreigners independence, activity, logic, ability to find and absorb new information; promotes the development of linguistic-regional competence, deepening of communicative skills; makes their speech more expressive, expands vocabulary, outlook; activates educational activity, develops Ukrainian way of thinking and imagination skills of foreigners. In our opinion, due to the fact that there is a difficult process of updating the educational system, the modernisation of the information and technological base of the educational process of higher education is not implemented sufficiently. Therefore, the issue of using information technologies at the lessons of Ukrainian as a foreign language requires further investigation. Our suggestions can be used in general courses of Ukrainian as a foreign language as well as in special courses of lexicology for foreign students. The suggested types of tasks can be used by teachers during the classes, and can also be introduced into the manuals in Ukrainian as a foreign language. The prospects of this research are seen in the deep study of phraseology with the use of the latest technologies in the field of intercultural and interlingual communication. The authors hope that the suggested paper will contribute to the development of Ukrainian linguodidactics, it can be used in the creation of substantial works in the field of teaching Ukrainian as a foreign language.

Thus, the results of experimental testing and oral questioning of foreign students lead to the conclusion: our suggested system of gradual study of phraseology with the use of IT technologies intensifies and improves the efficiency of the learning process, makes it more diverse, creative, interesting, and contributes to the motivation for learning a non-native language.

\section{References:}

Akkoyunlu, B., \& Soylu, M. Y. (2006). A Study on Students' Views About Blended Learning Environment. Turkish Online Journal of Distance Education-TOJDE3, 7, 43-56. Retrieved July 192019 from http://tojde.anadolu.edu.tr/ yonetim/icerik/makaleler/274-published.pdf

Arbaugh, J. B., Desai, A., Rau, B., \& Sridhar, B. S. (2010). A review of research on online and blended learning in the management disciplines: 1994-2009. Organization Management Journal, 7, 34-42. https://doi.org/10.1057/omj.2010.5

Azarova, L. E. (2015). Metodolohiia vykorystannia linhvo-informatsiinoho pidkhodu v doslidzhenni harmoniinoi pobudovy skladnykh nominatsii [Methodology of using linguistic information approach in the study of harmonious construction of complex nominations]. Metodychni studii, 4, 90-103. Retrieved Desember 252019 from http://ir.lib.vntu.edu.ua/handle/123456789/2254

Barmak, O., Mazurets, O., Krak, Iu., Kulias, A., Azarova, L., Gromaszek, K., \& Smailova, S. (2019). Information technology for creation of semantic structure of educational materials. Proc. SPIE 11176, Photonics Applications in Astronomy, Communications, Indastry, and High-Energy Physics Experiments, 1117623, Wilga, Poland. https://doi.org/10.1117/12.2537064

Boelens, R., Voet, M., \& Wever, B. (2018). The design of blended learning in response to student diversity in higher education: Instructors' views and use of differentiated instruction in blended learning. Computers \& Education, 120, 197-212. https://doi.org/10.1016/j.compedu.2018.02.009

Buhaichuk, K. L. (2016). Zmishane navchannia: teoretychnyi analiz ta stratehiia vprovadzhennia $\mathrm{v}$ osvitnii protses vyshchykh navchalnykh zakladiv [Blended Learning: Theoretical Analysis and Strategy for Introducing Higher Education in the Educational Process]. Information technologies and learning tools, 4 (54), 1-18. https://doi.org/10.33407/itlt.v54i4.1434

Gahina, N., \& Borysenko, V. (2018). Kontseptualni zasady zmishanoho navchannia v movnii osviti u vyshchii shkoli [Conceptual principles of blended learning in language education in higher education]. Pedahohichni nauky: teoriia, istoriia, innovatsiin i tekhnolohii, 1 (75), 174-184. Retrieved January 102020 from https://repository.sspu.edu.ua/handle/123456789/5055

Górska, D. (2016). E-learning in Higher Education. The Person and the Challenges. The Journal of Theology, Education, Canon Law and Social Studies Inspired by Pope John Paul II, 6 (2), 35-43. http://dx.doi.org/10.15633/pch.1868

Graham, C. R. (2005). Blended learning system: Definition, current end sand future direction. In Bonk, C. J., Graham, C. R. (Eds.), Handbook of Blended Learning: Global Perspectives, Local Designs (pp. 3-21). San Francisco, CA: Pfeiffer Publishing. Retrieved January 102020 from http://curtbonk.com/graham_intro.pdf 
Krak, I., Barmak, O., \& Mazurets. O. (2018).The Practice Implementation of the Information Technology for Automated Definition of Semantic Terms Sets in the Content of Educational Materials. In Ivan Sergienko, Philip Andon (eds.), CEUR Workshop Proceedings. Proceedings of the 11th International Conference of Programming UkrPROG'2018 (pp.245-254). Retrieved March 22020 from http://ceur-ws.org/Vol-2139/245-254.pdf

Krak, I., Barmak, O., \& Mazurets. O. (2016). The Practice Investigation of the Information Technology Efficiency for Automated Definition of Terms in the Semantic Content of Educational Materials. In In Ivan Sergienko, Philip Andon (eds.), CEUR Workshop Proceedings. Proceedings of the 10th International Conference of Programming UkrPROG'2016 (pp.237-245). Retrieved March 22020 from http://ceur-ws.org/Vol-1631/237-245.pdf

Krak, Iu. V., Barmak, O. V., \& Romanyshyn, S. O. (2014). The method of generalized grammar structures for text to gestures computer-aided translation. Cybernetics and Systems Analysis, 50(1), 116-123. https://doi.org/10.1007/s10559-014-9598-4

Krak, Y. V., Barmak, A. V., Bagriy, R. A., \& Stelya, I. O. (2017). Text entry system for alternative speech communications. Journal of Automation and Information Sciences, 49 (1), 65-75. https://doi.org/10.1615/JAutomatInfScien.v49.i1.60

Kudina, T., \& Kudin, A. (2014). Novitni tekhnolohii u vykladanni ukrainskoi movy yak inozemnoi v merezhevi ymovnii laboratorii [Newest technologies in teaching Ukrainian as a foreign language in a networking language laboratory]. Teoriia $i$ praktyka vykladannia ukrainskoi movy yak inozemnoi, 10, 17-25. Retrieved January 202020 from http://nbuv.gov.ua/UJRN/Timvum_2014_10_5

Lahuta, T. (2008). Frazeolohizmy yak aspekt vyvchennia leksyky ukrainskoi movy inozemnymy studentamy [Phraseologisms as an Aspect of Studying the Lexicon of the Ukrainian Language by Foreign Students]. Vykladannia mov u vyshchykh navchalnykh zakladakh osvity na suchasnomu etapi. Mizhpredmetni zviazky, 12, 136-141. Retrieved January 292020 from http://dspace.univer.kharkov.ua/handle/123456789/3123

Lisetskyi, K. A. (2015). Blended learning model in the system of higher education. Advanced Education, 4, 32-35. http://dx.doi.org/10.20535/2410-8286.51344

Lothridge, K. (2013). Blended learning: efficient, timely and cost effective. Australian Journal of Forensic Sciences, 45(4), 407-416. https://doi.org/10.1080/00450618.2013.767375

Luzik, E., Akmaldinova, O., \& Tereminko, L. (2019). Developing software engineering students' readiness for professional mobility through blended learning. Advanced Education, 13, 103-111. https://doi.org/10.20535/2410-8286.185230

Moebs, S., \& Weibelzahl, S. (2006). Towards a good mixin blended learning for small land medium size denterprises - Outline of a Delphi Study. In E. Tomadaki and P. Scott (Eds.), Innovative Approaches for Learning and Knowledge Sharing, EC-TEL 2006 Workshops Proceedings (pp. 10-17). Crete, Greece. Retrieved August 102019 from http://norma.ncirl.ie/1063/

Rogushina, J. (2016). Semantic Wiki resources and their use for the construction of personalized ontologies. Problems in programming, 2-3, 188-195. Retrieved March 12020 from http://pp.isofts.kiev.ua/ojs1/article/view/195

Roman, L. A. (2015). Informatsiini tekhnolohii yak innovatsiia u vykladanni ukrainskoi movy yak inozemnoi [Information technology as an innovation in teaching Ukrainian as a foreign language]. Scienceand Education a New Dimension. Pedagogy and Psychology, III(22), 45. Retrieved September $16 \quad 2019$ from https://seanewdim.com/uploads/3/4/5/1/34511564/roman_l.a._information_technology_as_an_innovation_in_teaching_ukr ainian_as_a_foreign_language.pdf

Simpson, A. J. (2016). The successful incorporation of blended learning into the Language curriculum. Advanced Education, 5, 96107. https://doi.org/10.20535/2410-8286.68608

Syzonov, D. (2018). Media Phraseology and the Dynamics of the Ukrainian Language: the Psycholinguistic and Stylistic Paradoxes. Psycholinguistics, 24(2), 277-291. https://doi.org/10.31470/2309-1797-2018-24-2-277-291

Yashchuk, O. (2014). Equivalence translation of phraseological synonyms. Advanced Education, 1, 83-88. https://doi.org/10.20535/2410-8286.29481

Ventura, J., \& Silva, J. (2007). New Techniques for Relevant Word, Ranking and Extraction. In J. Neves, M. Santos, and J. Machado (Eds.), EPIA 2007, LNAI 4874 (pp. 691-702). Springer. https://doi.org/10.1007/978-3-540-77002-2_58

Received: June 30, 2020

Accepted: September 25, 2020 


\section{Appendix 1}

Table 1. Use of information resources in the stages of studying phraseology

\begin{tabular}{|c|c|c|c|}
\hline \multirow{2}{*}{$\begin{array}{l}\text { Stages of studying } \\
\text { Ukrainian } \\
\text { phraseology }\end{array}$} & \multicolumn{3}{|c|}{ Types of IT } \\
\hline & Presentations & Online-dictionaries & Internet communications \\
\hline $\begin{array}{l}\text { 1. Presentation of } \\
\text { theoretical } \\
\text { information about } \\
\text { Ukrainian } \\
\text { phraseology }\end{array}$ & $\begin{array}{l}\text { Educational } \\
\text { presentation } \\
\text { "Phraseologisms are } \\
\text { Treasures of } \\
\text { Language" }\end{array}$ & $\begin{array}{l}\text { https://supermif.com/frazeologizm/ukr/ } \\
\text { фразеологічний-словник.html; } \\
\text { http://lcorp.ulif.org.ua/dictua/ }\end{array}$ & $\begin{array}{l}\text { Reference, information and country- } \\
\text { research materials in text, audio, video } \\
\text { format on the Internet }\end{array}$ \\
\hline $\begin{array}{l}\text { 2. Explanation of the } \\
\text { new phraseological } \\
\text { material }\end{array}$ & $\begin{array}{l}\text { PowerPoint } \\
\text { presentation } \\
\text { "Phraseological Lace } \\
\text { of the Ukrainian } \\
\text { Language" }\end{array}$ & $\begin{array}{l}\text { Online - translators; } \\
\text { electronic periodicals; } \\
\text { https://svitslova.com/idioms- } \\
\text { dictionary.html; } \\
\text { electronic collections (photos, videos) }\end{array}$ & $\begin{array}{l}\text { Items of information } \\
\text { portals and sites, applications, } \\
\text { programmes that support online } \\
\text { communication (Facebook, Viber, } \\
\text { Google Form); } \\
\text { YouTube video hosting } \\
\text { personal email,Skype, Viber, WhatsApp }\end{array}$ \\
\hline $\begin{array}{l}\text { 3. Performing } \\
\text { different types of } \\
\text { exercises in order to } \\
\text { consolidate what has } \\
\text { been learned }\end{array}$ & $\begin{array}{l}\text { Educational } \\
\text { presentation } \\
\text { "Phraseologisms. Step } \\
\text { by step" }\end{array}$ & $\begin{array}{l}\text { Wiktionary: "List of phraseologisms of } \\
\text { the Ukrainian language" } \\
\text { https://uk.wiktionary.org/wiki/Додаток } \\
\text { :Список_фразеологізмів_української } \\
\text { _мови }\end{array}$ & $\begin{array}{l}\text { Information and communication } \\
\text { platforms: Facebook, Google, social } \\
\text { platforms: Twitter, Viber, WhatsApp, } \\
\text { Skape; } \\
\text { YouTube video hosting }\end{array}$ \\
\hline $\begin{array}{l}\text { 4. Revision of the } \\
\text { material }\end{array}$ & $\begin{array}{l}\text { PowerPoint } \\
\text { multimedia } \\
\text { presentation } \\
\text { "Phraseological } \\
\text { Workshop" } \\
\end{array}$ & $\begin{array}{l}\text { http://slovopedia.org.ua/49/53392- } \\
\text { 0.html }\end{array}$ & $\begin{array}{l}\text { Off-line and on-line dialogue } \\
\text { communication, email, ICQ }\end{array}$ \\
\hline $\begin{array}{l}\text { 5. Performing certain } \\
\text { types of work in } \\
\text { order to test the } \\
\text { knowledge and skills } \\
\text { of foreign students }\end{array}$ & $\begin{array}{l}\text { Student's Power Point } \\
\text { presentation } \\
\text { (individual, paired or } \\
\text { group) "Let's compare } \\
\text { fraseologisms!" }\end{array}$ & http://rozum.org.ua & $\begin{array}{l}\text { Off-line and on-line polylogue } \\
\text { communication (conferences, forums, } \\
\text { chats, including native speakers); } \\
\text { e-mail correspondence; } \\
\text { online testing with the Google Drive } \\
\text { application }\end{array}$ \\
\hline
\end{tabular}

